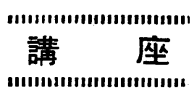

\title{
腐食に影響を与える諸因子（その 1$)^{*}$
}

G. V. Akimov

\section{緒}

腐食過程は多くの因子によって左右され，これらは多 くの場合互に独立化作用するものではなくて，これらの 問には複雑な相互作用がある。

腐食速度や分布を決める因子は，大きく二群に分類す ることができる。すなわち 1）外部因子，および 2）内 部因子とである。

外部因子とは，腐食の条件を規定するものである（す なわち，環境の性質に依存するもので，その化学組成と か，腐食を途滞させたり促進したりする物質の存在等)。 さらに，外部因子としては，電解液と金属との相対的運 動，温度や圧力を考光る。この外また，光の作用のよう にさほど重要でない因子もある。

腐食の内部因子は，金属自体汇関連したものである。 㵊も重要なのは，金属の化学的性質と組織とである。

内部因子のうち, 次いで重要なのは, 金属の内部歪と 変形，打よび表面状態である。最後に，これに関連して 特殊筀の腐食,つまり腐食疲労という現象を考光るべ きである。この現象は，腐食と機械的因子 (交番応力) とが同時に，金属に作用することに基因する。

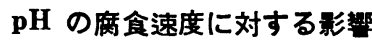

最も重要な外部因子は，もち万え金属が腐食を受け口 〉ある電解液の化学的性質である。きわめて一般的であ ると同時にきわめて重要な電解液の特性は, その $\mathrm{pH}$ 值で ある。従って腐食速度と分布とに対する電解液の性質の 影響を調べるのは，まず腐食速度の $\mathrm{pH}$ 依存性を調べる ことより始まる。まず最初, 液自体は酸化性ではないが, 不可避の要素として空父中の酸素が溶解している場合に ついて考光る。
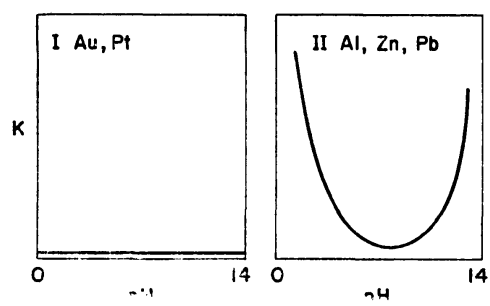

第 159 図 腐食と $\mathrm{pH}$ の関係を示す図（Akimov）
* 訳者: 前田正雄 電気通信研究所

(原文) Factors Influencing Corrosion, Corrosion, Vol. 15, No. 9, 455 t 468 t (1959) Sept.
腐食速度の $\mathrm{pH}$ 依存性を示す図型の，二，三の代表例 を画くことができる(第159図)。

はじめの最も単純な図形は金，白金のごとき貴金属の 場合の例である（第159図 I)。これらの金属では，腐食 速度の $\mathrm{pH}$ 依存性は, 横軸にきわめて近い直線で示され る。換言すれば，腐食速度はきわめて小さく，事実上ほ とえど液の $\mathrm{pH}$ によらないということを，この図は示し ている。 $\mathrm{pH}$ がきわめて高い場合は, わずかな直線の上 昇が観測される。つまり換言すれば，測定にか〉る程度 の腐食增加が認められる。しかしながら，実際上これは ほとんど問題とならない。

$\mathrm{pH}$-腐食速度図の第二型は，亜鉛，フルミニウム打よ び鉛といった技術的に重要な金属に対するものである (第 159 図 II)。図の示寸通り，これらの金属では酸，フ ルカリの両領域において，中性部分に比して，腐食はき わめて鋭い增加を示す。もちろん，各金属はそれぞれ特 有の腐食速度と特性曲線とを持ってはいるが，一般的な 形状はすべて同じである。上述の 金属の酸化物が，酸 およびアルカリの両環境において可溶性であることを考 虑すれば, このような形の曲線の得られることはうなら゙ ける。酸化亜鉛 $(\mathrm{ZnO})$ は, 酸性溶液中では塩を形成し て溶け, フルカリ性溶液中では錯化合物, すなわち亜鉛 酸ソーダという亜鉛酸塩を生成して溶ける。かくして, 酸およびアルカリの両溶液中で金属は保護被膜を失い, これによって腐食速度が，図の左右両端で増加すること が説明されることになる。曲線の上昇は，酸性領域にお いては, アルカリ性領域におけるよりも急激である。ま た一方，フルミニウムは，フルカリ中で容易にアルミン 酸化合物 $\mathrm{Na}_{3} \mathrm{AlO}_{3}$ を形成するために, アルミニウムの 酸化物は,フルカリ性領域におけるより,酸性領域で，よ り安定である。従って, アルミニウムに対する曲線は, フルカリ領域では急激に上昇し, 酸性領域ではゆるやか に上昇する。

第 160 図および第 161 図は， $\mathrm{Zn}$ と $\mathrm{Pb}$ に対する同じ 型の曲線を示したものである。最後に $\mathrm{pH}$-腐食図の第 三型を考元よう。これもまた， $\mathrm{Fe}, \mathrm{Ni}, \mathrm{Cd}, \mathrm{Mg}$ といっ た，非常に多くの実用上重要な金属に対するものである (第153図 III)。乙れらの金属は，フルカリ性領域にお いて，可溶性の錯化合物を形成しないので，その保護被 膜は溶解しないばかりでなく，溶解度が減少するため にむしろより安定となる。 
第 162 図は，水 酸化第一鉄の溶解 度と液の $\mathrm{pH}$ との 関係を示した。pH の增加に伴なって $\mathrm{Fe}(\mathrm{OH})_{2}$ の溶解度 は減少するので, 鉄の腐食速度もま た高い $\mathrm{pH}$ 領域 では減少する。酸 性領域では, 図の 第二型の場合と同 様に，腐食速度は 増加する（第 163 図)。

\section{ある種の金属,} 特に鉄の場合に は $\mathrm{pH}$-腐食図を きわめて高い $\mathrm{pH}$ 值（>14）にまで 拡张することがで きる。この領域で は, 高温 $\left(80^{\circ} \sim\right.$ $120^{\circ} \mathrm{C}$ 程度) に打 ける鉄の腐食速度 が増加する。従っ $\tau$, 鉄の場合非常 に高い $\mathrm{pH}$ 領域 では，図の第二型 の場合に似てく る。たら゙し，曲線 の水平部分がより 長くなっている点 だけが異なる。き わめて高温高浱度 のアルカリ中で は，鉄はいわゆる 鉄酸塩という錯 化合物を形成寸る という事実のため に，鉄の腐食が增 加するのである。 高濃度アルカリ中 で, 鉄が激しい粒 間腐食を生ずるこ とはよく知られて いる。この現象も

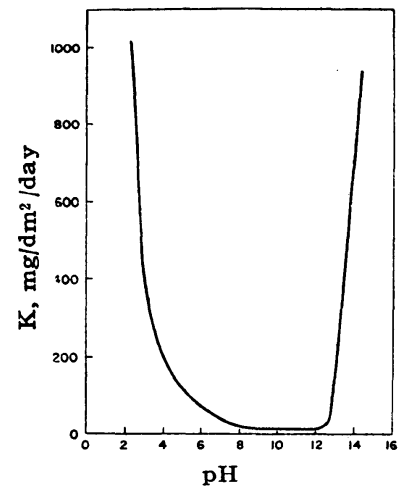

第 160 図严鉛の腐食の溶液の $\mathrm{pH}$ への依存性 (Roetheli, Cox および Littreal)

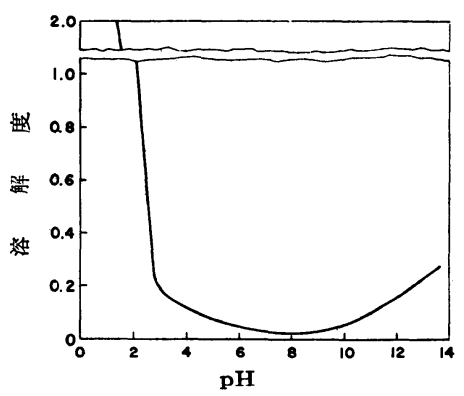

第 161 図鉛の腐食の溶液の $\mathrm{pH}$ へ の依存性 (Anderegg 特 よび Echatz)

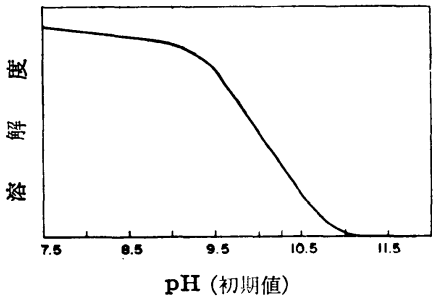

第 162 図 $\mathrm{NaOH}$ 溶液における水酸 化第一鉄の溶解度 (Whitman, Russeli お よび Davis)

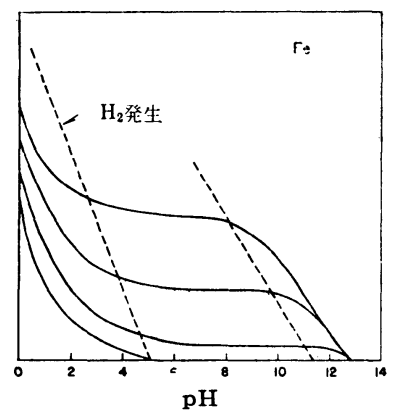

第 163 図鉄の腐食の液の $\mathrm{pH}$ に対 する関係 (Wilson)
また明らかに鉄酸塩の生成に基因している。すなわち粒 界に打ける電位が低下して水素を発生して鉄が腐食し得 る程度の值に達するのである。さらに溶液自体は酸化性 を持たないが，溶存酸素を含有する場合について考えて おく必要がある。しかしたとえば $\mathrm{HNO}_{3}, \mathrm{CH}_{3} \mathrm{COOH}$, 高 濃度の $\mathrm{H}_{2} \mathrm{SO}_{4}$ 溶液のごとく, 溶液自体が酸化性を有す る場合も多く知られている。腐食速度の $\mathrm{pH}$ 依存性は酸 化剂の存在のためにより一層複雑となる。

たとえば，硫酸中における鉄の腐食速度は，最初は酸 の濃度の増加に伴なって増大するが, 一定の濃度以上で は腐食度は 0 となる。これは, $\mathrm{H}_{2} \mathrm{SO}_{4}$ 濃度の増加ととも に，水素イオン濃度が増加するばかりでなく，硫酸溶液 の酸化性も同時に增加するからである。一定の(高い)濃 度に達して, 溶液の酸化性がかなりの程度に達すると, 鉄は不働態化する (第 6 章)。

硫酸よりもいくぶん強い酸化性を持つ溶液でも事情は 同じであるが，曲線はもっと低濃度で下方に曲る。

媒質が酸化性の場合だけでなく，活性な試薬の場合で も, 高濃度で金属上に保護的被膜が形成されるときには, 同じ型の曲線が得られる。よい一例は，鉛に対する硫酸 の作用である。この場合は広い濃度範囲にわたって硫酸 鉛の保護被膜が形成されるために，腐食速度は小さい。

\section{溶液中における抑制剤の作用 2 ,4)}

さて次に，他の外的因子，すなわち溶液中の酸素につ いて考えよう。この因子はきわめて重要で, 腐食過程に おいて重要な役㓶を演ずる。溶液中における酸素の影響 としては，腐食速度に関して互に相反する二つの観点か ら考光なければならない。第一に，酸素がよい復極剂で あることはよく知られている。ゆえに, 酸素の存在は陰 極反応の速度を増加させ，またこれが律速過程である場 合には，もちろ几腐食速度も増す。同時に，酸素は，多 くの金属上の保護的酸化被膜の安定性を増す。

鉄のごとき実用上重要な金属を含めて，多くの金属の 電極電位は, 溶液中の酸素濃度の増加に伴なって增すこ とをわれわれは既に知っている。また，酸化削は，乙 ばしば安定な保護的被膜の形成に必要であることも知っ ている。金属が空気に暴露されて形成された保護被膜 が，腐食の始まり易い弱点を持っているとすれば，溶液 中の酸化戍の濃度が高ければ高いほど, 酸化物の形成に よって，この弱点が塞がれ易くなるであろう。

従って，腐食過程において酸素の演ずる役割としては 二重のものを考える必要がある。一つは，酸素は復極削 として腐食を促進するし，また他方，保護被膜を修緬す ることによって腐食速度を低下させる。

このような問題を取り扱う場合に, “腐食確率”とい ら概念を導入する。与兄られた条件の下で，（鉄）板上 に, 腐食の発生を示す 4 個の点があると考えよう (“腐 
食中心”)。さらに，他の異なった条件下では，鉄の同 じ試片上に 20 個の腐食中心が見出されたとする。この ことを, 腐食確率が第一の場合は, 第二の場合における 1/5 であるという言葉で表現する。しかしながら，この ことは決して, 第二の試片における腐食速度も第一試片 の 5 倍であるということを意味しない。最近数年間に行 なわれた研究によると，一般的に言って，腐食確率が小 さければ小さいほど，その腐食中心における腐食速度は 大きい（すなわち，腐食反応速度は，腐食が一旦始をる と中心が少ないほど大きいであろう）ということを示し ている。従って，上例の鉄試片において，第二試片の腐 食確率は，第一試片のそれに比して非常に大きいにもか かわらず，各腐食中心における分解速度は，第一試片の 方が第二試片におけるよりも大きいだろうことが予想さ れる。しかしながら，このような言い方は，ごく大体の 意味で正しいに過ぎないのである。酸素の二重の影響を 考えると，上述のごとく酸素によって腐食確率が低下し 腐食の始をる活性中心の数（すなわち腐食核の数）が減 少するが，同時に，一旦腐食が始まるとその点，すなわ ち各腐食中心における腐食速度は増加することになる。 腐食を加速する゙物質は, しばしば腐食促進剤と呼ばれる。 腐食速度を低下させるものは腐食抑制剤と呼ばれる。酸 素はある場合には促進剤であるし，またある場合に法抑 制刜であると言える。これは強力な復極刜，つまり陰極 反応速度を加速することによって, 應食速度を増加させ るという意味では促進剤であり，また同時に保護被膜の 安定性を向上させる場合には抑制䠼となり得る。

従って, 溶液中の酸素が低濃度あるいは中程度の濃度 である場合には，腐食確率はいくぶえ減少するけれど も，普通は腐食速度が増す。腐食確率を減少させること は，決して有利なことではない。すなわち，実用的見地 から言うと好ましいことではない。なぜかというと腐食 中心は少ないにもかかわらず，その場所の腐食は，腐食 面積が大きい場合より速かに進行するからである。酸素 濃度が十分高く，腐食確率が0（すなわち，与えられた 条件下で金属が完全に不㗢態化する)である場合にのみ， 腐食中心が消失する。酸素濃度がより低い場合には完全 に不働態化する前に腐食速度が増すだけでなく激しい腐 食が数個の点に集中するので非常に悪い事態を招く。

腐食促進剤としての酸素の作用は，液の $\mathrm{pH}$ が低い注 ど著るしい。このことは，多くの金属上の保護被膜が酸 性溶液中で，より一層不安定となることに基因する。ア ルカリ溶液中では, 鉄やニッケルのごとき金属に対し て，酸素の抑制作用はきわめて顕著で，ごく少量の酸素 でも，しばしば，完全に腐食が止まる。

鉄に比して，銅はいくぶえ化学的安定性が高い。また 銅の保護被膜は酸素の作用の下では形成され難く，鉄の
被膜ほど高度の保護性を持たない。従って銅のような金 属に対しては，酸素は主として促進剤として働き，抑制 剤とはなり得ない。実際に, 実験データによると, 溶液 中の酸素濃度やその他の酸化剂によって, しばしば銅の 腐食速度がきまってしまうことが明らかにされている。 相当強い酸性溶液中でも, 酸化剂がないときには銅の腐 食はきわめて除々に進行するに過ぎない。しかしなが ら, 溶液中に空気よりの溶存酸素や, 硝酸のような酸化 郕が存在すると，銅はかなり早く腐食し酸化剂の濃度が 高いほど腐食速度は大きい。このような例を下に示す。

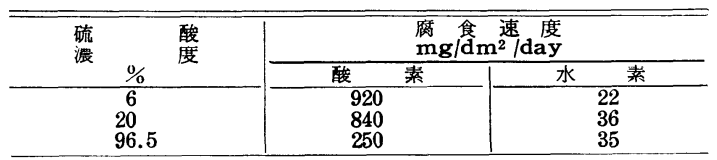

上の表から硫酸溶液上の雲囲気が酸素の場合には水素 の場合に比して腐食速度が数百倍大きいことが明らかで ある。従って促進戍および抑制戍としての酸素の二重性 を評価する場合金属の性質をも同時に考慮しなければな らない。鉄に対する酸素の抑制作用柱銅に対するより大 きい。この点に関してはアルミニウムの場合も同様であ る。抑制剤として働くと同時に促進剂ともなり得る物質 は酸素だけではない。溶液中で同じように働く化合物は 沢山ある。鉄の腐食の場合に, 重炭酸ソーダ $\left(\mathrm{NaHCO}_{3}\right)$ および酸性燐酸ソーダ $\left(\mathrm{Na}_{2} \mathrm{HPO}_{4}\right)$ を添加した場合の影 響については詳細な研究が行なわれている。これらの物 質の比較的少量によって腐食確率は低下するが腐食の始 まった点（腐食中心）の腐食を促進する。これらの物質 の濃度を一定量以上に引き上げることによって速度と腐 食確率の両者を0にすることができる。

$\mathrm{NaHCO}_{3}$ を種々の濃度で添加した $0.1 \mathrm{~N} \mathrm{NaCl}$ 溶液 中の鉄試片上の，腐食の分布状況を第 164 図に示した。

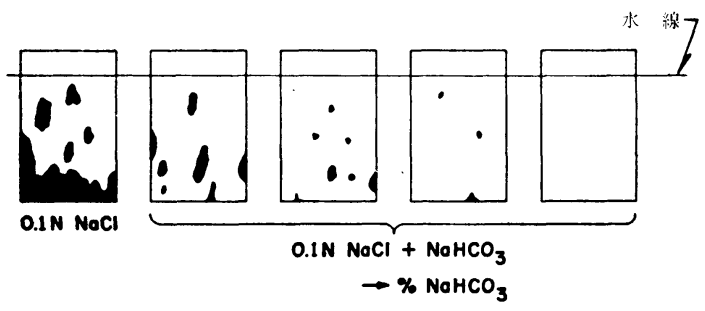

第 164 図種々の量の $\mathrm{NaHCO}_{3}$ を含む $0.1 \mathrm{~N} \mathrm{NaCl}$ 溶液中に打ける鉄試片の腐食分布 (Evans)

$\mathrm{NaHCO}_{3}$ を添加すると, 腐食部の全面積は急激に減少す ることが観取される。しかしながら，測定結果による と, 各腐食部位の強さ（腐食の）は激しく増大すること がわかる。相当量の重炭酸塩を添加して始めて, 完全に 防食される。金属試片が溶液中に完全に浸漬されている か, あるいは一部のみが浸漬されているかということ 
は，きわめて重要なことである。実際には，このような 水線部が存在する場合 (海水あるいは河川における舟艇, ガスタンク, 冷却器等）は非常に多い。 $\mathrm{NaCl}$ 溶液中に 半分だけ浸漬した普通の鉄試片では，第 164 図に示した ような腐食分布を示す。水線部位はほとんど腐食してい ない。これは，通気差電池を形成する酸素が，この部分 に十分供給されているからである。通気差電池では，試 片の水線部位と中間部はカソードとなるが，下方と側面 とはアノードとなって腐食するのである。

しかし，完全防食するに十分なだけの抑制剤が存在す ると，上と反対の現象が見られる。すなわち，腐食は水 線部位にあらわれる。これは，かような条件下では通気 差によって生ずベきカソード, アノードの分離が, 顕著 にあらわれないことに基因するのである。

アルカリ金属のクロム酸塩（すなわち $\mathrm{K}_{2} \mathrm{Cr}_{2} \mathrm{O}_{7}$ およ び $\mathrm{Na}_{2} \mathrm{Cr}_{2} \mathrm{O}_{7}$ ) は, 腐食速度を低下させるに有効である。 クロム酸塩は, 一般的不働態化剂と呼ぶことができる。 なぜならば，これらの化合物は腐食抑制戍だからであ る。中性溶液中に，ごく少量でもクロム酸塩を導入する と，腐食を完全に止めるに十分である。しかしながら， 酸素に関して確立した法則は，この種の抑制刜に対して もあてはまる（すなわち，ク口ム酸塩の量が不十分であ ると, 腐食が少数の点に集中されて, きわめて急速に侵 食されるゆえに，全然加えない場合よりもむしろ危険な 形態の腐食を生ずる)。普通，鉄，亜鉛および銅の腐食 を完全に抑制するには，クロム酸が 0.1 あるいは $0.01 \%$ 程度で十分だあると認められている。しかしながら，こ の量は, 腐食を促進する他物質（特に填化物）の溶液中 における存在によって著るしく左右される。

水素イオン濃度の増加に伴なって, クロム酸塩の抑制 作用汇減少する。そして, 溶液が十分酸性であると, ク 口ム酸塩は酸化剂となって, 強い復極作用を呈するゆえ に腐食がかえって増加する。従って，中性，「ルカリ性 あるいはきわめて弱い酸性溶液においてのみ, クロム酸 塩を抑制剂として利用することができる。

クロム酸塩が，鉄，垔鉛および銅の腐食に対して顕著 な影響を持っていることから，過マンガン酸塩，バナジ ウム酸および過酸化水素のごとき強酸化刘は, 強い不働 態化作用を持つと考えられさうである。しかしながら， この種の物質による抑制作用はきわめて小さく，腐食を 完全防止するためには，非常な大量を添加しなければな らないのである。上述したすべての抑制戍（すなわち， 酸素, 重炭酸ソーダおよびクロム酸塩）は陽極的抑制剂 と呼ばれる。これらによってアノード面積が減少するか らである。しかしながら, カソード面積を減少させるこ とによって，腐食速度を減少させるような陰極的抑制剤 がある。カソード面積の減少は不溶性化合物の生成を伴
ない,これによってカソードの活動力が弱められる。 陰極的抑制威の中に注, $\mathrm{Ca}\left(\mathrm{HCO}_{3}\right)_{2}, \mathrm{ZnSO}_{4}$, ある種 のニッケル化合物および多くのマグネシウム化合物があ る。これらの物質が溶液中に存在すると，不溶性の化 合物が形成され，これはカソード部位を覆い，カソード を溶液から絶縁する（すなわち，カソード面積が減少す る)。陰極的抑制凪は，安全な抑制風の部類に属する。 これらの溶液中における存在量の多少にかかわらず，常 に腐食速度は減少する。実用的見地から言えば，この場 合の腐食速度の減少注十分とは言えないかも知れない が，たとえどんな少量でも，このような抑制剤を添加し た場合は，陽極的抑制剤の添加量が不十分である場合に 見られるように，ある部分の腐食を加速増大させるよう なことはないのである。抑制戍の第三の部類は，ある種 の有機化合物のコロイドだある。この種の抑制剤は主と して酸性溶液中で有劫である。この種のものとしては, ゼラチン, 寒天, Sulfonate glue, キノリン誘導体, 多 くのアルカロイドその他がある。これらの抑制剤の特徵 は, 通常的 0.01 および $0.1 \%$ 程度の少量でも, 溶液 に添加した場合に，強い保護作用を示すということであ る。コロイド抑制剤の理論は，まだ十分に確立されてい ないけれども，大部分の研究者は，次のような説明を承 認しているようである。酸性溶液中では, 抑制剤のコロ イド粒子は正電荷を帯びる。従って局部電池の（電）場 の中で注，カソード部に向って運動する。局部カソード に吸着すると，コロイド粒子は水素過電圧を増大させ, 水素の放電が進行し得なくなる。良って金属の溶解はや むこととなる。

金属面のスケールを除去する酸洗作業において，コロ イド抑制剤は広く用いられている。この際問題となるこ とは，金属を溶解させずにスケールだけを溶解すること である。これは酸洗液に抑制剂を加えることによって達 成される。有機抑制剂のコロイド粒子は，アルカリ溶液 中で溳電荷を帯びるゆえに，これらがアルカリ溶液中 で抑制剤になり得るとは考えられない。全くまれな例で はあるが，実際問題として有機抑制剂が，中性およびア ルカリ性溶液中で有郊に働く場合のあることが見出され ている。しかし，中性溶液のみならず純水中でも，かな りの効果を持つ抑制戍を選定することのできる場合があ る。たとえば純水に $0.2 \%$ の寒天を添加すると，鉄の 腐食速度を初期值の $2.7 \%$ ，鉛のそれを $1.4 \%$ 減少せ しめ，さらに亜鉛の腐食を完全に防止する。

\section{溶液中の促進剤の作用}

前節においては，腐食を遅滞せしめる物質について考 えた。非常に重要な抑制剂一酸素一はをた促進剤として 作用し，そして酸素の作用は，溶液中におけるその濃度 と外的条件によって規定されることを既に述べた。媒質 
の役割りを評価する場合に，いつでも促進戍としてしか 働かないような物質の存在についても考えなければなら ない。この種の物質としてはまず第一に，いわゆる酸素 近伝体と呼ばれるものがある。鉄が腐食しつ〉ある溶液 中に，第二鉄塩が存在すると考える。これは第一鉄塩に 变り得て, 従って腐食を加速し得るので, よい復極剂で ある。溶液涳気と接しているので，さらに余分の酸素 が液中に入り得るであろう。復極反応の結果として形成 さ礼る第一鉄塩は，（溶解酸素の作用の下に）再び第二 鉄塩となる。後者は再びカソードで還元されて第一鉄塩 となりそれからをた酸化されるという過程を繰返えす。 かくして第二鉄塩の存在は，これが酸素の伝達体となる た氻に腐食過程にかなり加速することになる。第二銅塩 も，銅の腐食に際して上述と同じ作用をする。いわゆる 錯化全物を形成する物質も, 非常に強力な促進郕となる。 金属イオンと作用して錯化合物を形成するようなイオン が溶液中に存在する場合がある。これは金属イオン濃度 を低下せしめる作用を有し，従って金属の電極電位を低 下せしめる。錯化合物を形成する促進棛としてはシフン 化物があり，これは酸素が存在すると銀や金のごとき金 属に対してすら，その腐食を非常に加速する。

アンモニウム化合物とアンモニヤ水は，銅に対しては きわめて有害である。溶液中にこれらの化合物が存在す ると, complex copper ammoniate が形成され，これ は金属表面における銅イオンの濃度を非常に低下させ， 従って腐食を促進する。このような錯化合物は，酸素の 存在の下においてのみ形成されるということは強調され るべきことである。アンモニヤとアンモニウム塩それ自 体は酸素が存在しなければ銅の腐食過程をそれ汪ど加速 することはできない。不溶性の物質として金属イオンを 沈殿させるようなイオンもまた液中に存在する場合があ る。このような場合は，不溶性物質が金属表面に形成さ れない限り抑制作用は起らない。従ってこれらのイオン の存在は金属面における金属イオンの濃度を低下せしめ る。金属表面上に沈殿するかたい 不溶性化合物 の中に は，ほとえぞ保護性を持たず，往々にしてこの沈殿を惹 起するイオンの存在の下に腐食がきわめて加速されると いったようなものである。硫化物はこの種の物質の代表 的なものである。銅および鉄の硫化物はほとえど保護性 を持たず，また一般的に言って硫化物が形成されると銅 および鉄の腐食は促進される。この現象注金属表面にお ける金属イオン濃度の低下と関連している。

\section{中性塩港度の影筫}

正確な測定によると，多くの場合，腐食速度の中性塩 濃度への依存性は，一つの極大を持つ曲線によって示さ れる（第 165 図)。極大の位置は，塩や金属の種類によ ってそれぞれ異なる。

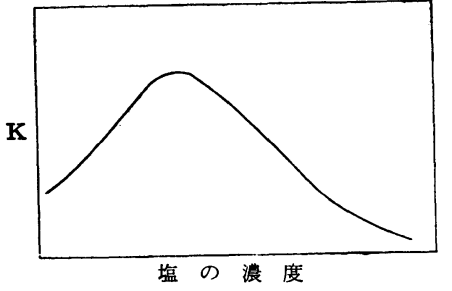

第 165 図

溶液中の塩濃度と腐食速 度との関係を示す代表的 曲線
曲線の上昇する 部分は濃度の増加 に伴なって溶液の 電気電導度が増加 乙, 従って腐食電 流が增すためであ る。さらに $\mathrm{Cl}^{\prime}$, $\mathrm{SO}_{4}{ }^{\prime \prime}$ のごとき陰 イオン濃度の増加 は, 被膜の保護性 を低下させ，従って腐食速度を増大せしめることがわか っている。しかしながら, 電解液中の塩の濃度の增加に 伴って酸素の溶解度が低下し(第 166 図), 復極反応速度 が低下し従って,

腐食速度が隇少す るに違いない。か くして, 塩の浱度 が一定值に達する と, 溶液中の酸素 濃度の欠乏が顕著 になるものと予想 される。このよう にして，極大を有 する曲線を説明す ることができる。

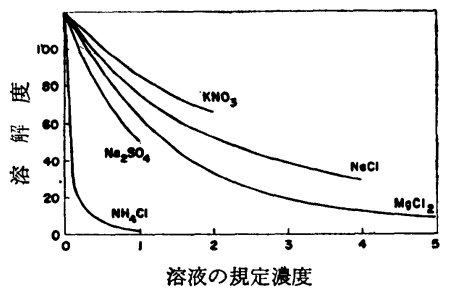

第 166 図 $25^{\circ} \mathrm{C}$ における溶液中の 塩濃度の関数としての, 酸素の溶解度。純水中の 溶解度を 100 とする (Speller)
曲線の降下部分は, 酸素の欠乏の影響が, 液の電導度の 増加および被膜の保護性の低下の影響よりも顕著にあら われるような濃度に達したことを示寸ものである。

\section{溶液の運動速度の影辈}

さて, 次のような因子, すなわち溶液の運動速度の影 響を考学ることにしよう。ここでの事情は，溶液の運動 速度の増加がしばしば他の因子にも影響をもたらすため に，きわめて複雑である。すなわち，種々の因子の相互 作用が，溶液の運動だけの影響を抽出することを困難に しているのである。

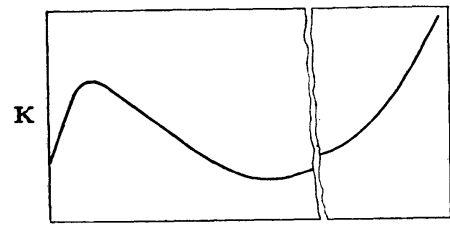

溶液の流動速度

第 167 図腐食速度の溶液の流動速 度に対する関係
中性溶液中の鉄 の腐食速度と運動 速度との関係は, 第 167 図に示して ある。腐食速度は 最初増加し, 次い で低下し始める。 そして最後に, 非

常に高速度領域では再び急激に增加する。曲線の最初の 部分に対する説明は比較的簡単である。空気中よりの酸 素を含む中性溶液中では，腐食は酸素の復極作用の下で 進行する。従って溶液の運動速度の増加は, 酸素の補給 
を増加せしめ, 従って復極作用を増す。液の運動速度を もっと増した場合には曲線の降下が見られるが、これを 説明するのはもっと難しい。しかし，いくつかの説明を 与えるのは可能である。最も確からしい説明は, 恐らく 酸素が十分供給さ狆て鉄が不働態化するということであ ろう。換言すれば，酸素の供給がきわめて十分であっ て，その抑制作用が，加速作用を凌嘿するのである。し かしながら, 溶液の運動速度の増加と共に, 腐食速度の 降下が起らないで連続的に増加するような場合にも，こ のような状態があらわれる。たとえば, 溶液が定常的に 流れているような場合の, 管の腐食の場合に見られる。

酸性領域においては, 中性の場合に比して, 溶液の運 動速度の影響はそれほど顕著ではない。鉄の腐食に関し ては, 多くの場合流速の增加は, 腐食速度に大した影響 を及ぼさないことがわかっている。第 167 図は，流速が 一定值を越えると, 腐食が急速に増加することを示して いる。このことは, 流速が大きくなると, 特別な型の腐 食，すなわちいわゆる衝撃腐食が発生するという事実に 基因する。金属面を急速に流れる溶液が，腐食作用によ って生成した。あるいは腐食開始前に存在していた保護 被膜を剩離する作用を持つために，大きな腐食が惹起さ れるのである。非常な高速度においては，金属は束実上 なんら，保護被膜を持たない状態で腐食するのである。

衝撃腐食の例は，大量の水が高速で流れている黄銅コ ンデンサーチューブの腐食である。流速が急激に変化す る場所で衝撃が生じ, 黄銅のコンデンサーチューブの保 護被膜の表面が破壊され，こつで局部的な衝撃腐食が始 まる。もっと高速になると, 興味ある現象が生ずる。こ の場合には, 流速の増加だけでなく, いわゆるキャビテ ーション（衝突を起す非常な高速流体の内部に，泡沫あ るいは空洞が形成されること）が大きな影響を持つ。キ ヤビテーションに関連した破壊現象は, 最近の軍艦用蒸 気関 (スクリュー) の推進器, 水力タービンの翼のよう な部分に見られる。キャビテーションによる推進器の破 壊は非常に急速に始まり，ある場合には始動後数時間に して始まり，局部的な金属の欠削よりなると見られる。 最近の研究では, キャビテーション腐食は純粋な機械的 因子が主たる原因であり, 電気化学的因子·の影響は小さ いことが示されている。

\section{温度の影㬎}

化学反応速度論の考察から, 腐食速度を他の化学反応 之同様, 温度の上昇に伴なって増加するに相違ないと予 想される。実際に多数の腐食反応について, 腐食速度の 急激な上昇が見られ，この関係恃通常指数関数曲線をも ってあらわされる(第 168 図)。酸あるいは水道水中の亜 鉛の腐食速度の温度依存性は, このような型である

169 图)。

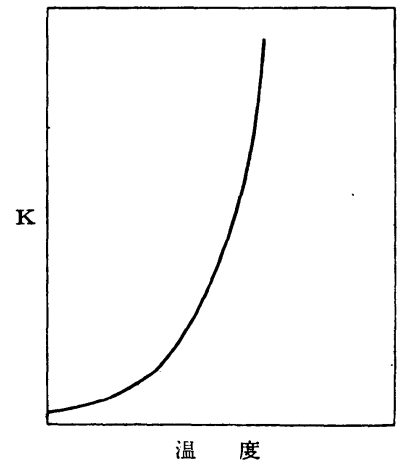

第 168 図腐食速度と温度との 関係を示す関数

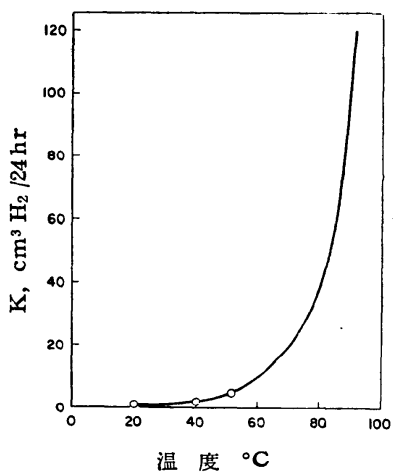

第 169 図水道水中の覀鉛腐食 の温度に対する関係 (Baylis)

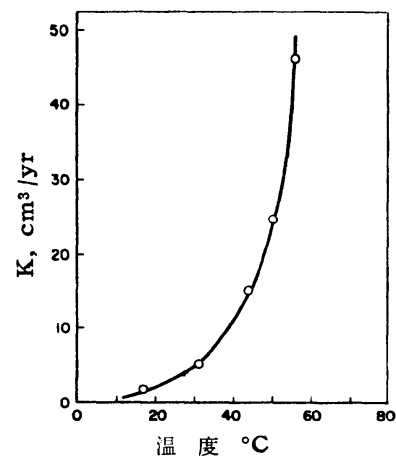

第 170 図 $18 \% \mathrm{HCl}$ 溶液中におけ る鉄腐食の温度との関係 (Conroy)

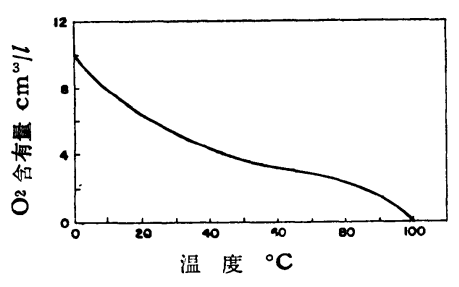

第 171 図気圧 $760 \mathrm{mmHg}$ におけ る水中の酸素の溶解度。 温度の関数として示す
しかしながら， 腐食の分野では， 腐食速度と温度と の関係が指数関数 曲線で示されるよ うな単純な場合だ けではない。多く の場合, 温度变化 によって他の腐食 因子も変化する。 たとえば, 酸素の 復極作用によって 腐食が進行する埸 合には，温度上昇 は二つの異なった 作用を有すること を考慮しなければ ならない。一つに は, 温度上昇が通 則通り腐食を加速 し，また対流電流 や拡散を促進する ということであ る。他方, 温度上 昇によって空気中 よりの酸素の溶解 度が減少し(第171 図)，彷って，溶 液中の酸素湡度が 温度上昇とともに 低下する。それゆ え, 温度上昇は最 初は腐食を加速す るが, 温度が更に 上昇すると溶液中 の酸素濃度がきわ めて低くなるた め, 腐食速度は減 少するであろう。 実際データはこの 予想を確かめてい る。第 172 図は温 度の関数としての 鉄の腐食速度を示 している。 温度上昇に伴な って溶液から酸素 
が逃げ去ることの できる場合には (開放系)，極大を 有する曲線が得ら れる。極大を越元 てからの曲線の傾 斜は，溶液中の酸 素が欠そするとい う事実によって説 明される。酸素が 溶液より逃散し得 ない場合は（密 閉系), 腐食速度 は温度上昇ととも に連続的に増加す る。同じ説明が,

\section{第 173 図および第}

174 図の曲線に 対 して適用される。 これらはそれぞ れ，硫酸中のモネ ル, $10 \% \mathrm{NaCl}$ 溶 液中における銅の 腐食速度に対する 温度の影響を示し たものである。

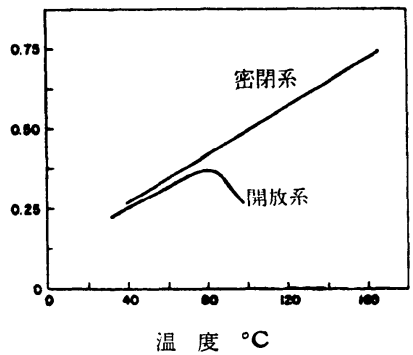

第172図密閉系および開放系にお ける, 純水中の鉄の腐食 速度と温度の関係 (Speller)

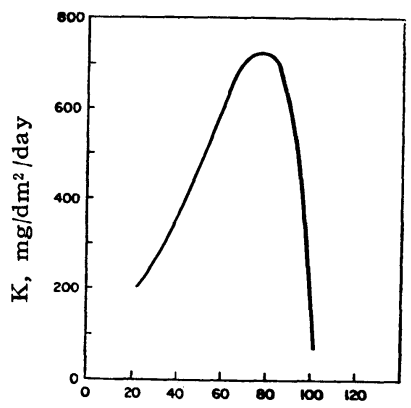

温度 ${ }^{\circ} \mathrm{C}$

第 173 図空気飽和 $6 \%$ 硫酸中に打 けるモネルの腐食速度と 温度との関係(Mckay 拈 よび Worthington)

最後に, 腐食に対する温度の影響を評価する場合, 保 護被膜の特性をも考慮に入れなければならない。これが 温度に依存する場合には, 腐食速度の变化は, 乙ばしば この被膜特性の温度依存性に帰することができる。

蒸留水中の亜鉛の腐食に関する実験は, きわめて示唆 に富む（第 175 図）。温度が $50^{\circ} \mathrm{C}$ から上昇を始好る 伴なって, 腐食速度は最初上昇し, 極大に達し, 次いで

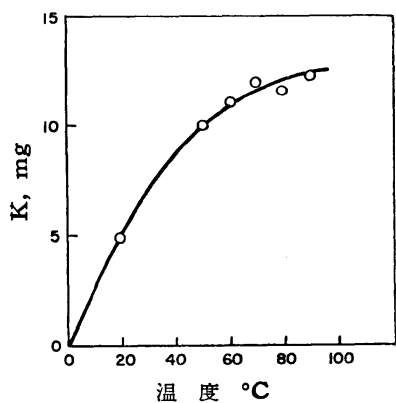

第174図 $10 \% \mathrm{NaCl}$ 中におけ る銅の腐食速度と温 度との関係 (Reich 打よび Colb)。試験 時間 $2 \mathrm{hr}$
急激に 0 となる。 $50^{\circ} \sim 90^{\circ} \mathrm{C}$ の温度範 囲では，金属上に形 成される被膜は，ほ とえど保護性を持た ないが, この範囲以 下および以上では高 度の保護性を持つ。

\section{迷走電流による腐} 食

迷走電流は，管路 および鉛被ケーブル のごとき地下埋設の 金属体に対して激し

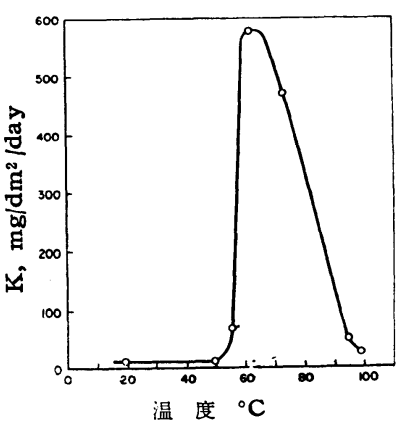

第 175 図水道水中の亜鉛の腐 食の温度依存性 (Cox)
い障害を惹起する。

第 176 図は，いかに して迷走電流が発生 するかを模型的に示 した。

大地の抵抗がそれ ほど大きくなけれ 证，軌道に沿って䡛 流すべき直流注分岐 して，その一部は近 接の管路に沿って流 れる。電流江直接 に，あるいは地下ヶーブルのごとき他の導体を通って； 他の点から軌道に杘る。電流が管路に移入する点はカソ ードで，管路より流出する点がアノードとなる。電流が

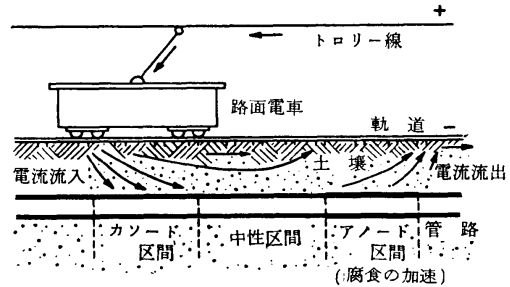

第176図路面電車の軌道から分流して, 地中管路を通 って流れる電流およびカソードとアノード部 分の形成を示す (Akimov)

地中に厌り，そして他の導体に移入寸る範囲にある管路 およびケーブル区間（すなわちアノード区間）は強い腐 食を受ける。電流が地中に流入する部分では, 軌道も腐 食する。腐食は陽極型である。すなわち外部電源による 金属の溶解（アノード）の際绩ずる腐食と同じである (第 177 図)。

この場合の腐食 は，陰陽両極部が 空間的漓隹孔てい るために，きわめ て広い範囲にわた るものであり，従 って,しばしば見 られるように反応 の進行を遅滞させ るような保護被膜

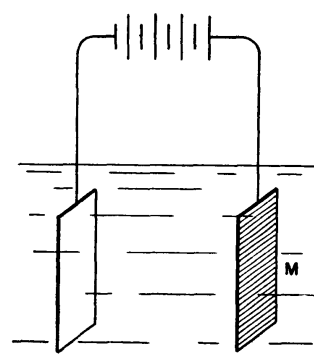

カソード フノード

第 177 図試片 $\mathrm{M}$ のアノード 腐食
が，陰陽両極部における腐食生成物の相互作用によって 生ずるということがない。迷走電流の存在は，単純な実 験室的試験によって示すことができる。第 178 図は，陰 陽両極部の検出のためにフェロキシルを指示薬として添 加し，更にその部分の着色が冕散するのを防ぐためにゼ ラチンを添加した $\mathrm{NaCl}$ 溶液中に浸漬した, 1 本の銅線 
$A B \rightleftarrows$ 示してい る。純鉄板を銅線 に平行に浸清して ある。銅線の抵抗 がきわめて小さい と，電流はこの總 だけ通って流 れ，雷流が溶液中 を分流して鉄板に 流入するというこ

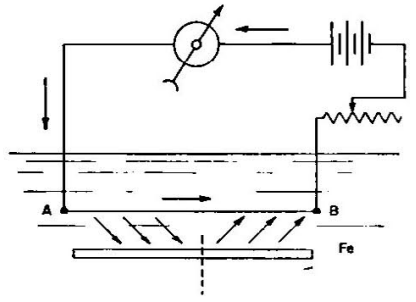

第 178 図迷走電流の娭出のため の実娩室試験

(Akimov)
とはない。しかしながら，掜動抵抗を用いて回路の抵抗を 增して行くと, 電流の一部は, 抵抗最小の途, つまり溶 液，鉄板を通って，再び佂液，銅線に戻ることになる。 このことは，鉄板のカソード部が赤色に，フノード部が 青に并色することによって明瞭に锥察される。導体 AB においても，そのカソード卸分すなわも電流が流入する 点に出いては青に看色する。腐食電流の大いさをきるる 電動力流，迷走電流の存在の下においてはきわいて大き く，很ってカソード部では，気体水素の発生すら見られ る。1A の電流は 1 年間に, 鉄の約 $10 \mathrm{~kg}$, 銅の $11 \mathrm{~kg}$ あるいは鉛の $37 \mathrm{~kg}$ を腐食する。

第 179 图および第180図は，鋳鉄管および亜鉛管の腐 食例て示した。迷走電流による鉛被の腐食は,しばしば 䊀䦌鹰食の形態を示すゆえに，特に危除である。つまり このような場合は腐食量が比較的小さくても，ケーブル に対して決定的な障悹となるのである。

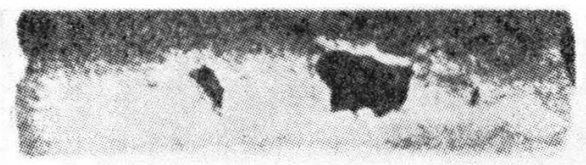

第 179 図迷走電流による障害を受けた鉡鉄管 (Mass)

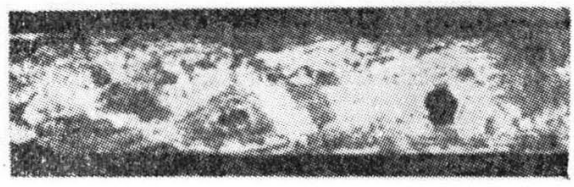

第 180 図迷走電流による障害を受けた亜鉛管 (Mass)

電流が金属体だけを通って流れ地中に分流して再び流 出与るこ々がなけ机は迷走電流による腐食はない。金属 体（たとえは軌道）より地中あるいは他の導体に流出す る電流が大きいほど迷走電流による腐食量は大きい。

導体之地中管路開の動電力法, 多くの因子 (導体の電 位，導休と管路との相刘位置および土裹の比抵抗等）に 依孙する。測定結果によれば，動電力の值はしばしば 0.65 と $4.5 \mathrm{~V}$ の間の値をとる。電流密度もまた非常に 大きく変化する。電流密度が $0.1 \sim 0.3 \mathrm{~mA} / \mathrm{dm}^{2}$ の場合
には局部鹰食が辛うじて認められる程度である。0.3〜 $0.7 \mathrm{~mA} / \mathrm{dm}^{2}$ では，腐食中心に打ける糜食速度が增大 し， $0.5 \sim 2.0 \mathrm{~mA} / \mathrm{dm}^{2}$ 程度の電流密浱では，管路のき わめて激しい侵食が認められる。往々にして速走電流の 大きさは，例外的に大きな值になる。たとえばニューヨ 一ク地区に打いて, ラッシュ時に, 6 in 水湴管に $70 \mathrm{~A}$ の電流の流机た例がある。土境の型はまた，きわめて重

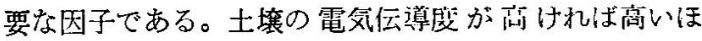
ぞ，他の条件を同じこすれば，土壤中や优の等体に分流 する電流は大きい。迷走電流の管は, 砂質士壤中よりむ 粘土中における方が大きい。迷走電流に刘する保護対策 としては，次の方法がある。すなわち

1）溥体（軌道）の電導性を增す。つまり，路面電車 の軌道の接繶を完全にし, 軌道からの介师電線の数を增 す。また軌道の下に，砂利のような電算性の悪い䋓縁層 を就に重要である。

2）管路や他の金属休を，絶縁物（フスフォルト，湓 青) で被覆すること。しかし品行の悪い紿縁被覆は，フ ノード部分に抢いて，腐食を小数部们に集中させ，一層 激しくするゆ元に，斯態要化させる。

3）電流の排流を行なうこと。ある埸仝には，すべて の地下金属体を相互に接続し，一括して潩導体に接繶す ることによってよい線果が得られる。この場合は，電流 が金属体中のみを流机て，地悛には流入しないと考えて よい。しかしながら，この方法の適用が適切でない場 合，つまり，地下導体を相互陪繶するとき，接続洩れが あって排流菜統に含まれないものがあるとここの学体の 腐食が加速されることがある。䧔極扐食の適用もまた有 效である。迷走電流は土、コンクリートウの補強用鉄枠に, 非漥に激しい腐食を生ずる。特に，凍綃を防止する目的 で、コンタリートに盗化物が加亲られている場合に激し い腐食が起る。このたらコンクリートは霞導性となり， 塩秦イオンは，フルカリ性コンクリートの作用で釷面に

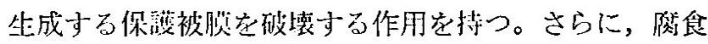
反応によって生成与る鉄の篮化物はアルカリ性コンクリ 一トと作用して水酸化第一鉄堂尘成し，ての体程が增加

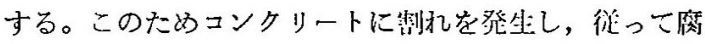

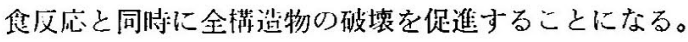

迷太電流は電鉄以外のものからも発自:する。工場に京

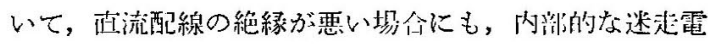
流安生じ，これは，条件が悪いと箈路や，浴槽，機械そ の他の装置に腐食を生ずる。ドック中の船船の溶接作拝 中, 電流端子の一方が船体に接繥されてあると, 迷走電 流を生じて船の腐食の原因となる。船巾の不完全な配線 (絶緣が恶いとか，一線式の場合）は，迷走需流を生じ て船体の鉄板および吃水線下のリベットに腐食を生ず る。 (次号に続く) 